\title{
Hubungan CXC Chemokine Receptor 4 (CXCR4) dan Matrix Metalloproteinase 9 (MMP 9) dengan Kemampuan Metastasis Adenokarsinoma Prostat
}

\section{Correlation of CXC Chemokine Receptor 4 (CXCR4) and Matrix Metalloproteinase 9 (MMP 9) in Prostate Adenocarcinoma Metastasis}

\author{
Sri Murtiyani, Bethy S. Hernowo, Sri Suryant? \\ Anatomi Pathology Department, Faculty of Medicine, Universitas \\ Padjajaran, Bandung
}

\begin{abstract}
KATA KUNCI Adenokarsinoma prostat, CXCR4, metastasis, MMP 9, non metastasis

KEYWORDS Prostate adenocarcinoma, CXCR4, metastases, MMP-9, non metastases
\end{abstract}

ABSTRAK Karsinoma prostat merupakan keganasan kedua terbanyak pada laki-laki dan merupakan penyebab kematian kelima diseluruh dunia. Faktor prognosis utama pada adenokarsinoma prostat adalah metastasis yang menyebabkan tingginya angka kematian. Keadaan ini disebabkan karena pada kasus adenokarsinoma prostat yang metastasis pilihan terapi belum mendapatkan hasil yang memuaskan karena terdapat faktor resisten terhadap terapi radiasi dan kemoterapi. CXCR4 dan MMP 9 merupakan petanda imunohistokimia yang berfungsi dalam proses migrasi, chemotaxis dan detachment yang memegang peranan terhadap terjadinya metastasis pada adenokarsinoma prostat. Tujuan penelitian ini adalah mencari hubungan imunoekspresi CXCR4 dan MMP 9 dengan metastasis pada adenokarsinoma prostat.

Penelitian ini menggunakan desain potong lintang dan observasional analitik. Sampel diambil dari blok parafin yang tersedia di Departemen Patologi Anatomi RSUP Dr. Hasan Sadikin Bandung pada periode 2010-2016. Jumlah sampel sebanyak 52 sampel, dibagi menjadi 2 kelompok, yaitu kelompok metastasis 26 sampel dan kelompok non metastasis 26 sampel. Keseluruhan sampel dilakukan pulasan imunohistokimia CXCR4 dan MMP 9.

Hasil penelitian ini menunjukkan bahwa $71 \%$ sampel mengekspresikan CXCR4 kuat dengan proporsi terbesar pada kelompok metastasis (nilai $p=0,000$ ) dan 56\% sampel 
mengekspresikan MMP 9 lemah pada kelompok metastasis (nilai $p=0,55$ ).

CXCR4 dapat digunakan sebagai faktor prediksi metastasis pada adenokarsinoma prostat.

ABSTRACT Prostate carcinoma is the second most common malignancy in males and the fifth leading cause of death worldwide. The major prognostic factor in prostate adenocarcinoma is metastases leading to high mortality. This is because in cases of prostate adenocarcinoma the metastases of treatment options have not resulted in satisfactory remediation due to resistant factors to radiation therapy and chemotherapy. CXCR4 and MMP-9 are immunohistochemical markers that function in the migration, chemotaxis and detachment processes including metastases in prostate adenocarcinoma. The aim of this study is to find the relationship between CXCR4 and MMP 9 immunoexpression with metastases in prostate adnocarsinoma.

A cross sectional study with an observational analytical design were applied. Samples were taken from paraffin blocks available from the Department of Anatomical Pathology of Dr. Hasan Sadikin Bandung during the period of 2010-2016. The total samples were 52 cases, devided into 2 groups consisted 26 cases of metastases groups and 26 cases of non metastases group. All samples were stained with immunohistochemistry for CXCR4 and MMP 9.

The results of this study showed that $71 \%$ of all samples have strong CXCR4 expression whereas the largest proportion is in metastases group ( $p$ value 0,000$)$ and $56 \%$ of all samples have weak MMP 9 expression in metastases group ( $p$ value 0,55$)$.

CXCR4 can be used as a predictor for metastases in prostate adenocarsinoma.

\section{PENDAHULUAN}

Adenokarsinoma prostat (AKP) adalah invasif karsinoma yang terdiri dari sel epitelial prostatik neoplastik disertai diferensiasi pola histomorfologikal yang beraneka macam, terdiri dari kelenjar, cords, dan single cells, sedangkan tipikal sel basal tidak ditemukan. Karsinoma prostat merupakan masalah kesehatan yang penting karena merupakan jenis karsinoma terbanyak kedua diseluruh dunia dengan rata-rata 1,1 juta dan memiliki angka kematian paling banyak kelima pada laki-laki dengan rata-rata angka kematian 307.000 pada tahun 2012 (Holger Moch 2016). Adenokarsinoma prostat primer berlanjut menjadi metastasis melalui proses terlepasnya sel-sel tumor, migrasi lokal secara invasi ke pembuluh darah, dan sistem limfatik (intravasasi).

\footnotetext{
Correspondence:

Sri Murtiyani, Anatomi Pathology Department, Faculty of Medicine, Universitas Padjajaran, Bandung. Email:sri.murtiyani@gmail.com
} 
Pada aliran darah, sel-sel tumor masuk ke dalam sistem sirkulasi kemudian sel-sel tumor keluar dari pembuluh darah (ekstravasasi) sampai ke lokasi metastasis pada jaringan target (Kingsley et al., 2007). Metastasis merupakan salah satu faktor yang menentukan prognosis adenokarsinoma prostat karena menyebabkan tingginya angka kematian. Hal ini disebabkan karena pada adenokarsinoma prostat yang metastasis pilihan terapinya masih terbatas. Radioterapi dan kemoterapi belum dapat meningkatkan angka harapan hidup dibuktikan dengan sering terjadi rekurensi dan resistensi (Felgueiras et al., 2014). Metastasis terjadi melalui beberapa proses dan beberapa faktor yang terlibat, yaitu proses migrasi, angiogenesis, dan detachment (Kingsley et al., 2007).

Faktor yang berperan pada proses metastasis diantaranya adalah CXCR4 dan MMP 9. C-X-C chemokine receptor 4 (CXCR4) adalah sepasang protein $G$ receptor chemokine terletak pada kromosom 2 berikatan dengan stromal cell derived factor 1(SDF-1) atau CXC ligand 12 (CXCL12) (Liu et al., 2014, Domanska et al., 2013). Chemokine adalah peptides dengan berat 8-12 $\mathrm{kDa}$ merupakan famili proinflamatory cytokine yang mengatur beraneka macam respon imun pada infeksi, inflamasi, dan perbaikan jaringan. CXCR4 berfungsi sebagai cell survival, proliferasi, chemotaxis, migrasi, adhesi, angiogenesis, dan metastasis (DarashYahana et al., 2004, Zhao et al., 2015, Luker and Luker, 2006). Ekspresi CXCR4 memiliki peranan penting pada metastasis karsinoma dan progresi beberapa macam tipe karsinoma termasuk karsinoma prostat (DarashYahana et al., 2004, Zhao et al., 2015, Luker and Luker, 2006, Zhu et al., 2016).
Yan Xi Sun (2005) mengatakan ekspresi CXCR4 meningkat signifikan pada karsinoma prostat lokal dan metastasis. Matrix metalloproteinases (MMPs) adalah endopeptides yang memiliki kemampuan untuk mendegradasi protein extracellular matrix. MMP dikenal mendegradasi beberapa sel membran dan protein pericelullar terdiri dari prekursor sel membran pada faktor pertumbuhan, faktor pertumbuhan berikatan dengan protein, reseptor faktor pertumbuhan, dan molekul sel adhesi (Merdad et al., 2014). MMP merupakan kelompok utama enzim proteolitik yang berperan dalam invasi, angiogenesis, dan metastasis. Anggota famili MMP yang memiliki enzymatic activity against type IV collagen yang paling tinggi yaitu MMP-2 dan MMP-9. (Mehmet Topqul, 2014) Matrix metalloproteinase 9 (MMP-9) adalah zinc dependent peptidase yang merupakan subfamilli gelatinase pada MMPs, memiliki berat $92 \mathrm{kDa}$. MMP 9 memiliki kemampuan degradasi denaturasi kolagen (kolagen tipe IV) yang merupakan komponen membran dasar (Elsa Yullus, 2014, Wu et al., 2014, Zheng et al., 2006). Elnas M. Yousef (2014) mengatakan ekspresi MMP-9 yang meningkat pada karsinoma payudara terdapat hubungan dengan metastasis.

Penelitian ini bertujuan untuk melihat imunoekspresi CXCR4 dan MMP-9 pada adenokarsinoma prostat yang bermetastasis sehingga diharapkan dapat menjadi penanda imunohistokimia terhadap prediksi terjadinya metastasis dan dapat digunakan sebagai terapi target baru.

\section{METODE}

Penelitian ini adalah penelitian observasional analitik dengan pendekatan cross sectional yang 
dilakukan di Laboratorium Patologi Anatomik RSUP Dr.Hasan Sadikin Bandung dengan menggunakan blok parafin, sediaan pulasan hematoksillineosin dan arsip hasil pemeriksaan histopatologik penderita adenokarsinoma prostat dalam periode 2010-2016 yang memenuhi kriteria inklusi. Data kejadian metastasis diperoleh dari rekam medis penderita yang tersimpan di Rekam Medik RSUP Dr. Hasan Sadikin Bandung.

Blok parafin yang dipilih yang mengandung cukup sel tumor dan diberi pulasan imunohistokimia dengan menggunakan CXCR4 rabbit polyclonal antibody (Boster Biological Technology) dengan pengenceran 1:100. Ekspresi protein CXCR4 dinilai secara visual dengan mikroskop cahaya binokuler dan dibuat skor secara semikuantitatif dengan menghitung jumlah sel tumor yang menunjukkan imunoreaktivitas pada sitoplasma rata-rata pada 10 lapang pandang besar (pembesaran 400x). Distribusi sel $0=$ tidak ada, $1=<10 \%, 2=10-50 \%, 3=51-80 \%, 4=>80 \%$. Intensitas $0=$ tidak ada, 1=lemah, $2=$ sedang, $3=$ kuat. Histoskor (distribusi $x$ intensitas); lemah $=0-6$, kuat $=8-12$ (Zhao et al., 2014). Pulasan imunohistokimia MMP 9 rabbit polyclonal antibody (Gene Tex USA) dengan pengenceran 1:100. Imunoreaktivitas pada sitoplasma ratarata pada 10 lapang pandang besar (400x). Distribusi sel $0=$ tidak ada, $1=1-$ $10 \%, 2=10-50 \%, 3=51-70 \%, 4=70-100 \%$. Intensitas $0=$ tidak ada, $1=$ lemah, 2=sedang, 3= kuat. Histoskor (distribusi $x$ intensitas); lemah $=0-4$, kuat $=6-12$ (Koskensalo et al., 2012).

Hubungan ekspresi CXCR4 dan MMP 9 dengan metastasis adenokarsinoma prostat dianalisis dengan menggunakan uji Chi-square, apabila syarat Chi-square tidak terpenuhi maka dilakukan uji Exact Fisher dengan tabel $2 \times 2$. Kemaknaan pada penelitian ini ditetapkan pada $\mathrm{p}<0,05$.

\section{HASIL}

Pada penelitian ini, sampel diambil dari blok parafin penderita adenokarsinoma prostat yang dilakukan tindakan core biopsy, TURP, dan prostatektomi. Data penelitian tersebut diambil pada periode 20102016. Sampel penelitian yang telah memenuhi kriteria inklusi didapatkan sebanyak 26 sampel untuk masingmasing kelompok, yaitu kelompok metastasis dan non metastasis ke tulang dan organ lain. 
Tabel 1. Data Klinikopatologi Adenokarsinoma Prostat

\begin{tabular}{|c|c|c|}
\hline \multirow[b]{2}{*}{ Variabel } & \multicolumn{2}{|c|}{ Kelompok } \\
\hline & $\begin{array}{l}\text { Metastasis } \\
\mathrm{N}=26(\%)\end{array}$ & $\begin{array}{l}\text { Non metastasis } \\
\qquad \mathrm{N}=26(\%)\end{array}$ \\
\hline \multicolumn{3}{|l|}{ Jenis Pengambilan sampel } \\
\hline - Core biopsy & $6(37 \%)$ & $10(63 \%)$ \\
\hline - TURP & $20(57 \%)$ & $15(43 \%)$ \\
\hline - Prostatektomi & $0(0 \%)$ & $1(100 \%)$ \\
\hline \multicolumn{3}{|l|}{ Usia } \\
\hline 45-75 tahun & $19(44 \%)$ & $24(56 \%)$ \\
\hline$>75$ tahub & $7(78 \%)$ & $2(22 \%)$ \\
\hline Mean & 70,04 & 67,85 \\
\hline Median & 69,5 & 68 \\
\hline SD & 9,77 & 8,38 \\
\hline \multicolumn{3}{|l|}{ PSA } \\
\hline$<10 \mathrm{ng} / \mathrm{ml}$ & $1(50 \%)$ & $1 \quad(50 \%)$ \\
\hline $10-20 \mathrm{ng} / \mathrm{ml}$ & $2(100 \%)$ & $0 \quad(0 \%)$ \\
\hline$>20 \mathrm{ng} / \mathrm{ml}$ & $23(48 \%)$ & $25(52 \%)$ \\
\hline \multicolumn{3}{|l|}{ Histopatologi (Grading) } \\
\hline $\begin{array}{l}\text { - Gleason score } 6 \text { (well } \\
\text { differentiated) }\end{array}$ & $2(100 \%)$ & $0(0 \%)$ \\
\hline $\begin{array}{ll}\text { - } & \text { Gleason score } 7 \\
\text { (moderately } \\
\text { differentiated) }\end{array}$ & $9(75 \%)$ & $3(25 \%)$ \\
\hline $\begin{array}{ll}- & \text { Gleason score } \geq 8 \\
& \text { (poorly differentiated) }\end{array}$ & $15(39 \%)$ & $23(61 \%)$ \\
\hline
\end{tabular}

Pada tabel 1 menjelaskan bahwa karakteristik jenis pengambilan sampel core biopsy terbanyak terdapat dalam kelompok non metastasis, yaitu 10 kasus (63\%), TURP terbanyak pada kelompok metastasis, yaitu 20 kasus (57\%), sedangkan prostatektomi merupakan jenis pengambilan sampel terkecil. Karakteristik usia 45-75 tahun terbanyak terdapat dalam kelompok non metastasis, yaitu 24 kasus (56\%) sedangkan pada usia $>75$ tahun terbanyak terdapat pada kelompok metastasis, yaitu 7 kasus (78\%). Kadar PSA 10-20ng/ml terbanyak pada kasus metastasis, yaitu 2 kasus (100\%), sedangkan kadar PSA >20ng/ml terbanyak pada kasus non metastasis, yaitu 25 kasus (52\%). Karakteristik histopatologi (grading) didapatkan jumlah well differentiated merupakan yang terkecil dibandingkan dengan kelompok moderately differentiated dan poorly differentiated. Well differentiated dan moderately differentiated terbanyak terdapat pada kelompok metastasis, yaitu 2 kasus (100\%) dan 9 kasus (75\%), sedangkan poorly differentiated terbanyak terdapat dalam kelompok non metastasis, yaitu 23 kasus (61\%). 
Tabel 2. Hasil Imunoekspresi CXCR4 pada kelompok metastasis dan non metastasis Adenokarsinoma Prostat

\begin{tabular}{|c|c|c|c|c|c|c|}
\hline \multirow{3}{*}{ Imunoekspresi } & \multicolumn{4}{|c|}{ Kelompok } & \multirow{3}{*}{$\mathrm{T}$} & \multirow{3}{*}{ Nilai P } \\
\hline & \multicolumn{2}{|c|}{ Metastasis } & \multicolumn{2}{|c|}{$\begin{array}{c}\text { Non } \\
\text { metastasis }\end{array}$} & & \\
\hline & $\mathrm{N}$ & $\%$ & $\mathrm{~N}$ & $\%$ & & \\
\hline \multirow{2}{*}{$\begin{array}{r}\text { CXCR4 L } \\
\text { K }\end{array}$} & 2 & 11 & 16 & 89 & 18 & \multirow[t]{3}{*}{$0,000^{* *}$} \\
\hline & 24 & 71 & 10 & 29 & 34 & \\
\hline Total & 26 & 50 & 26 & 50 & 52 & \\
\hline
\end{tabular}

Nilai p pada variabel kategori dengan uji Chi-square tetapi menggunakan alternative uji Fishers exact apabila syarat dari Chi-square tidak terpenuhi. Nilai kemaknaan berdasarkan nilai $\mathrm{p}<0,05$. Tanda ** menunjukan $\mathrm{p}$ value $<0,05$ artinya signifikan atau bermakna secara statistik.

Uji statistik dengan Fishers exact memberikan nilai $\mathrm{p}=0,000(\mathrm{p}<0,05)$, yang berarti bahwa imunoekspresi CXCR4 mempunyai nilai yang signifikan atau bermakna terhadap metastasis.

Tabel 3. Hasil imunoekspresi MMP 9 pada kelompok metastasis dan non metastasis Adenokarsinoma Prostat

\begin{tabular}{|c|c|c|c|c|c|c|c|}
\hline \multirow{3}{*}{\multicolumn{2}{|c|}{ Imunoekspresi }} & \multicolumn{4}{|c|}{ Kelompok } & \multirow{3}{*}{$\mathrm{T}$} & \multirow{3}{*}{ Nilai P } \\
\hline & & \multicolumn{2}{|c|}{ Metastasis } & \multicolumn{2}{|c|}{$\begin{array}{c}\text { Non } \\
\text { Metastasis }\end{array}$} & & \\
\hline & & $\mathrm{N}$ & $\%$ & $\mathrm{~N}$ & $\%$ & & \\
\hline \multirow[t]{2}{*}{ MMP 9} & $\mathrm{~L}$ & 9 & 56 & 7 & 44 & 16 & $0,548^{*}$ \\
\hline & K & 17 & 47 & 19 & 53 & 36 & \\
\hline \multicolumn{2}{|l|}{ Total } & 26 & 50 & 26 & 50 & 52 & \\
\hline
\end{tabular}

Nilai p pada variabel kategorik dengan uji Chi-Square. Tanda * menunjukkan $\mathrm{p}$ value $>0,05$ artinya tidak signifikan atau tidak bermakna secara statistik.
Uji statistik dengan Chi-Square mendapatkan hasil $\mathrm{p}=0,548(\mathrm{p}>0,05)$, yang berarti bahwa imunoekspresi MMP-9 mempunyai nilai yang tidak signifikan atau tidak bermakna terhadap metastasis. 

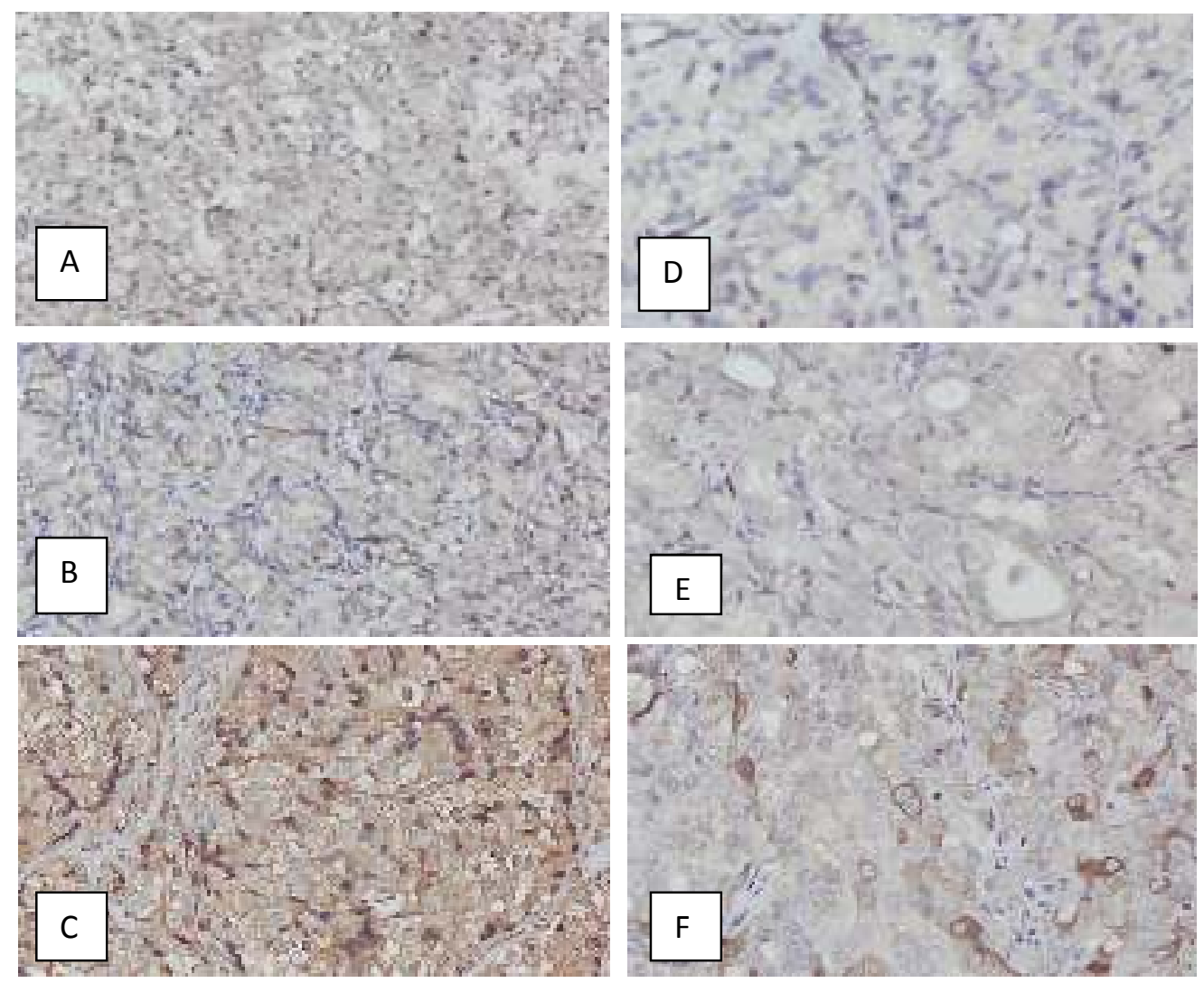

Gambar 1. Adenokarsinoma Prostat (AKP). (A) Ekspresi lemah CXCR4. (B) Eskpresi sedang CXCR4. (C) Ekspresi kuat CXCR4. (D) Ekspresi lemah MMP 9. (E) Ekspresi sedang MMP 9. (F) Ekspresi kuat MMP 9.

\section{PEMBAHASAN}

Karakteristik usia penderita adenokarsinoma prostat pada penelitian ini berkisar dalam rentang usia 45-75 tahun yang terbanyak pada kelompok non metatasis, yaitu 24 kasus $(56 \%)$ sedangkan rentang usia $>75$ tahun yang terbanyak pada kelompok metastasis, yaitu 7 kasus (78\%). Median usia antara kelompok non metastasis dan metastasis tidak terlalu berbeda, hanya berbeda 1,5 tahun kelompok metastasis lebih tua dibandingkan kelompok non metastasis. Berdasarkan WHO 2016 insidensi adenokarsinoma prostat terbanyak adalah pada usia $>60$ tahun (Holger Moch, 2016). Penelitian AB Weiner (2016) mengatakan terjadi peningkatan secara signifikan pada kasus karsinoma prostat dengan rentang usia 55-69 tahun pada kelompok metastasis, yaitu 702 kasus pada tahun 2004 menjadi 1345 kasus pada tahun 2013 (meningkat 92\%). Penelitian Elsa Yullus (2014) kelompok usia terbanyak pada kasus karsinoma prostat adalah 65-74 tahun, yaitu 11 kasus (64,7\%). Penelitian Valdo (2016) kelompok usia terbanyak pada kasus karsinoma prostat di Manado adalah 6170 tahun, yaitu 20 kasus (37\%). Penelitian Anandia Putriyuni (2014) kelompok usia terbanyak pada kasus karsinoma prostat di Padang adalah 6170 tahun, yaitu 63 kasus (38,65\%).

Berdasarkan karakteristik PSA, kadar PSA >20ng/ml yang terbanyak pada kelompok non metastasis, yaitu 25 kasus (52\%) sedangkan kadar PSA 10-20 
$\mathrm{ng} / \mathrm{ml}$ yang terbanyak pada kelompok metastasis, yaitu 2 kasus (100\%). Penelitian Seok Jin Jung (2011) didapatkan karsinoma prostat mean PSA adalah 7,6 ng/ml. Penelitian Damien Poussel mengatakan kadar PSA pada karsinoma prostat $>4 \mathrm{ng} / \mathrm{ml}$ terdapat 20 kasus dari 28 kasus (71\%). Penelitian Elsa Yullus (2014) dari 17 kasus penderita karsinoma prostat yang tercatat kadar PSA pada suku Sunda dan Jawa memiliki kadar PSA (median) 26,7 ng/ml. Penelitian Valdo R.Solang (2016) dari 34 kasus penderita karsinoma prostat di Manado yang tercatat kadar PSA memiliki kadar PSA $>100 \mathrm{ng} / \mathrm{ml}$ adalah terbanyak, yaitu 17 kasus (50\%). Penelitian Anandia Putriyuni (2014) dari 36 kasus karsinoma prostat di Padang yang tercatat kadar PSA memiliki kadar PSA $>20 \mathrm{ng} / \mathrm{ml}$ adalah terbanyak, yaitu 30 kasus $(83,33 \%)$.

Berdasarkan

karakteristik grading, kasus well differentiated memiliki jumlah terkecil. Kasus moderately differentiated terbanyak pada kelompok metastasis, yaitu 9 kasus (75\%) sedangkan kasus poorly differentiated terbanyak pada kelompok non metastasis, yaitu 23 kasus (61\%). Penelitian Seok Jin Jung (2011) didapatkan kasus moderately differentiated dan poorly differentiated adalah 58\%. Pada penelitian Xin Wei Diao (2015) kasus karsinoma prostat poorly differentiated adalah terbanyak, yaitu 56 kasus dari 148 kasus (38\%). Penelitian Anandia Putriyuni (2014) dari 163 kasus karsinoma prostat di Padang yang memiliki derajat histopatologi terbanyak adalah poorly differentiated, yaitu 76 kasus (46,63\%). Beberapa penelitian terdahulu menunjukan data yang serupa untuk distribusi kadar PSA dan grading histopatologi terbanyak.

Pada penelitian ini didapatkan sebagian besar sel tumor mengekspresikan CXCR4 kuat pada kelompok metastasis, yaitu 71\%. Hasil statistik menunjukkan hubungan antara ekspresi CXCR4 dengan kemampuan metastasis pada adenokarsinoma prostat (nilai $\mathrm{p}$ value $=0,000$ ). Semakin tinggi ekspresi CXCR4 maka semakin tinggi pula kemugkinan terjadinya metastasis. Hasil ini sesuai dengan penelitian Mie A. Mohamed dan Azza Abdel Azis (2011) berdasarkan kasus pada karsinoma kolorektal dan Zheng wang (2006) pada kasus karsinoma pankreas, overekspresi CXCR4 100\% terjadi pada invasi lymphovascular, KGB, dan metastasis. Berbeda berdasarkan Shengqiang Zhao (2014) pada kasus intrahepatic cholangiocarcinoma terdapat kasus metastasis $66,7 \%$ yang overekspresi dengan CXCR4. Berdasarkan penelitian Joo Yong Lee (2014) mengatakan tingginya ekspresi CXCR4 pada adenokarsinoma prostat berhubungan dengan metastasis tetapi tidak berhubungan dengan gleason score atau T stage.

Imunoekspresi MMP 9 lemah pada kelompok metastasis, yaitu 56\%. Hasil statistik menunjukkan tidak ada hubungan antara ekspresi MMP 9 dengan kemampuan metastasis pada adenokarsinoma prostat (nilai $\mathrm{p}=0,55$ ). Hal ini sesuai dengan hasil penelitian sebelumnya yaitu berdasarkan penelitian Selja Koskensalo (2012) yang mengatakan pada kasinoma kolorektal ekspresi MMP-9 tidak berhubungan dengan Dukes stage atau stadium, lebih sering positif pada kasus lokal (Dukes A,B) atau stadium I,II tumormelewati dinding usus, Dukes B atau stadium II= invasi melewati dinding usus, otot 
tetapi tidak ke KGB, Dukes $\mathrm{C}$ atau stadium III= invasi ke KGB, Dukes D atau stadium $\mathrm{IV}=$ metastasis.

\section{KESIMPULAN}

CXCR4 dapat dijadikan sebagai faktor prediksi metastasis pada adenokarsinoma prostat. Peningkatan ekspresi CXCR4 berperan terhadap kemampuan metastasis pada adenokarsinoma prostat.

\section{Ucapan Terima Kasih}

"Saya ucapkan terima kasih kepada Prof. Dr. Med Tri Hanggono Achmad,dr -Rektor Universitas Padjadjaran, Dr. Yoni Fuadah Syukriyani, dr.,Sp.F.,DFM -Dekan Fakultas Kedokteran Universitas Padjadjaran, Ayi Djembarsari, dr.,MARS -Direktur Utama RS Dr. Hasan Sadikin Bandung, Dwi Prasetyo, dr., SpA(K)., M.Kes -Ketua Program Pendidikan Dokter Spesialis I, Prof. Bethy S.Hernowo. dr., SpPA(K).,PhD Kepala Departemen Patologi Anatomi dan ketua tim pembimbing, Sri Suryanti,dr. MS., SpPA(K) -Ketua Program Studi Patologi Anatomi Fakultas Kedokteran Universitas Padjajaran dan anggota tim pembimbing, Ismet M.Nur, dr., SpPA(K).,MM - Staf Pengajar Departemen Patologi Anatomi FKUP/RSHS, Dr.Abdul Hadi Hasan, dr.,SpPA(K), M.Kes -Staf Pengajar Departemen Patologi Anatomi FKUP/RSHS, Birgitta Maria Dewayani, dr.,SpPA(K), M.Kes -Staf Pengajar Departemen Patologi Anatomi FKUP/RSHS, Herry Yulianti ,dr. SpPA(K), M.Kes -Staf Pengajar Departemen Patologi Anatomi FKUP/RSHS, Afiati, dr., SpPA(K), M.M.Kes -Staf Pengajar Departemen Patologi Anatomi FKUP/RSHS,
Hasrayati Agustina,dr. SpPA.M.Kes Staf Pengajar Departemen Patologi Anatomi FKUP/RSHS, Anglita Yantisetiasti, dr.,SpPA., M.Kes -Staf Pengajar Departemen Patologi Anatomi FKUP/RSHS, Hermin Aminah,dr.,SpPA(K)., -Staf Pengajar Deprtemen Patologi Anatomi FKUP/RSHS, Silvi Kintawati, drg.,M.S Staf Pengajar Departemen Patologi Anatomi FKUP/RSHS, Murnisari Darjan, drg., M.S -Staf Pengajar Departemen Patologi Anatomi FKUP/RSHS."

\section{KEPUSTAKAAN}

Anandia Putriyuni NH 2014. Adenokarsinoma Prostat : Penilaian Prognostik Dan Derajat Histopatologi. Jurnal Mka-Fk.Unand, 37, 93-100.

Darash-Yahana M, Pikarsky E, Abramovitch R, Zeira E, Pal B, Karplus R, Beider K, Avniel S, Kasem S, Galun E \& Peled A 2004. Role Of High Expression Levels Of Cxcr4 In Tumor Growth, Vascularization, And Metastasis. Faseb J, 18, 1240-2.

Domanska UM, Kruizinga RC, Nagengast WB, Timmer-Bosscha H, Huls G, De Vries EGE \& Walenkamp AME 2013. A Review On Cxcr4/Cxcl12 Axis In Oncology: No Place To Hide. European Journal Of Cancer, 49, 219-230.

Elsa Yullus IP, Anna Tjandrawati, Dewi Kartika 2014. Keabsahan Engrailed-2 Di Kanker Prostat Indonesian Journal Of Clinical Pathology And Medical Laboratory, 20, 150-153.

Felgueiras J, Silva JV \& Fardilha M 2014. Prostate Cancer: The Need For Biomarkers And New Therapeutic Targets. Journal Of Zhejiang University. Science. B, 15, 16-42.

Holger Moch PAH, Thomas M Ulbright, Victor E Reuter 2016. Tumours Of The Prostate. Who Classification Of Tumours Of The Urinary System And Male Genital Organs. Fourth Ed. Switzerland: 
International Agency For Research On Cancer (Iarc) Lyon.

Jung SJ, Kim CI, Park CH, Chang HS, Kim BH, Choi MS \& Jung HR 2011. Correlation Between Chemokine Receptor Cxcr4 Expression And Prognostic Factors In Patients With Prostate Cancer. Korean Journal Of Urology, 52, 607-611.

Kingsley LA, Fournier PG, Chirgwin JM \& Guise TA 2007. Molecular Biology Of Bone Metastasis. Mol Cancer Ther, 6, 2609-17.

Koskensalo S, Hagström J, Linder N, Lundin M, Sorsa T, Louhimo J \& Haglund C 2012. Lack Of Mmp-9 Expression Is A Marker For Poor Prognosis In Dukes' B Colorectal Cancer. Bmc Clinical Pathology, 12, 24.

Lee JY, Kang DH, Chung DY, Kwon JK, Lee H, Cho NH, Choi YD, Hong SJ \& Cho KS 2014. Meta-Analysis Of The Relationship Between Cxcr4 Expression And Metastasis In Prostate Cancer. The World Journal Of Men's Health, 32, 167175.

Liu CF, Liu SY, Min XY, Ji YY, Wang N, Liu D, Ma N, Li ZF \& Li K 2014. The Prognostic Value Of Cxcr4 In Ovarian Cancer: A Meta-Analysis. Plos One, 9, E92629.

Luker KE \& Luker GD 2006. Functions Of Cxcl12 And Cxcr4 In Breast Cancer. Cancer Letters, 238, 30-41.

Mehmet Topqul EC 2014. The Biology Of Cancer Metastasis. 1-20.

Merdad A, Karim S, Schulten HJ, Dallol A, Buhmeida A, Al-Thubaity F, Gari MA, Chaudhary AG, Abuzenadah AM \& AlQahtani MH 2014. Expression Of Matrix Metalloproteinases (Mmps) In Primary Human Breast Cancer: Mmp-9 As A Potential Biomarker For Cancer Invasion And Metastasis. Anticancer Res, 34, 1355-66.

Mohamed MA \& Abdel-Aziz A 2011. Evaluation Of Cxcr4 Chemokine Receptor As A Prognostic Marker In Colorectal Carcinoma. Egyptian Journal Of Pathology, 31, 19-24.
Sun YX, Schneider A, Jung Y, Wang J, Dai J, Wang J, Cook K, Osman NI, Koh-Paige AJ, Shim H, Pienta KJ, Keller ET, Mccauley LK \& Taichman RS 2005. Skeletal Localization And Neutralization Of The Sdf1(Cxcl12)/Cxcr4 Axis Blocks Prostate Cancer Metastasis And Growth In Osseous Sites In Vivo. Journal Of Bone And Mineral Research, 20, 318-329.

Valdo R.Solang AM 2016. Profil Penderita Kanker Prostat Di Rsup Prof.Dr.R.D.Kandou Manado Periode Tahun 2013-2015. Jurnal E-Clinic, 4, 938.

Weiner AB, Matulewicz RS, Eggener SE \& Schaeffer EM 2016. Increasing Incidence Of Metastatic Prostate Cancer In The United States (2004-2013). Prostate Cancer Prostatic Dis, 19, 395-397.

Wu QW, Yang QM, Huang YF, She HQ, Liang J, Yang QL \& Zhang ZM 2014. Expression And Clinical Significance Of Matrix Metalloproteinase-9 In Lymphatic Invasiveness And Metastasis Of Breast Cancer. Plos One, 9, E97804.

Xin Wei Diao JYF, Qin Wen Wang, Jian Guo Sun 2015. Sdf-1/Cxcr4 Axis Promotes Prostate Cancer Cell Invasion And Bone Metastasis Through P38, Nf-Kb And Hif-1pathways. Int J Clin Exp Pathol, 2706-17.

Zhao H, Guo L, Zhao H, Zhao J, Weng H \& Zhao B 2015. Cxcr4 Over-Expression And Survival In Cancer: A System Review And Meta-Analysis. Oncotarget, 6, 5022-40.

Zhao S, Wang J \& Qin C 2014. Blockade Of Cxcl12/Cxcr4 Signaling Inhibits Intrahepatic Cholangiocarcinoma Progression And Metastasis Via Inactivation Of Canonical Wnt Pathway. Journal of Experimental $\mathcal{E}$ Clinical Cancer Research : Cr, 33, 103.

Zheng H, Takahashi H, Murai Y, Cui Z, Nomoto $K$, Niwa $H$, Tsuneyama $K$ \& Takano Y 2006. Expressions Of Mmp-2, Mmp-9 And Vegf Are Closely Linked To Growth, Invasion, Metastasis And 
HUBUNGAN CXC CHEMOKINE RECEPTOR 4 (CXCR4) DAN MATRIX METALLOPROTEINASE 9 (MMP 9) DENGAN KEMAMPUAN METASTASIS ADENOKARSINOMA PROSTAT

Angiogenesis Of Gastric Carcinoma. Anticancer Res, 26, 3579-83.

Zhu X, Bai Q, Lu Y, Lu Y, Zhu L, Zhou X \& $\mathrm{Wu} \mathrm{L}$ 2016. Expression And Function Of Cxcl12/Cxcr4/Cxcr7 In Thyroid
Cancer. International Journal of Oncology, 48, 2321-2329. 